\title{
Kewenangan Komisi Pemberantasan Korupsi dalam Penyidikan Kasus Simolator SIM (Kapolri VS KPK)
}

\author{
R. Nazriyah \\ Fakultas Hukum Universitas Islam Indonesia \\ Jl. Taman Siswa No. 158 Yogyakarta \\ ririesnaya@yahoo.com
}

\begin{abstract}
The research is aimed at finding out which institution, the Corruption Eradication Commission (KPK) or the Indonesian National Police (POLRI), actually has the authority to conduct investigations in the driving simulator case because both institutions stated that they had the authority. This research uses a normative approach supported by legal approach and case study. The type of data is secondary data. The data sources include primary legal materials, secondary legal materials, and tertiary legal materials. The research finding is that according to Law No.30 Year 2002 on Corruption Eradication Commission, Article 50, the Corruption Eradication Commission has the authority to conduct investigations. This authority is also strengthened by the statement of President Susilo Bambang Yudhoyono. To settle the dispute between KPK and POLRI, the President stated in his speech on 8 October 2012 that the driving simulator case involving Inspector General Djoko Susilo should be handled by KPK. Moreover, considering the Memorandum of Understanding among Corruption Eradication Commission, Indonesian National Police, and Attorney General, the authority should be given to KPK.
\end{abstract}

Key words : Authority, Corruption Eradication Commission (KPK), investigation

\begin{abstract}
Abstrak
Penelitian ini difokuskan untuk mencari institusi manakah yang sebenarnya berwenang antara KPK dan Kepolisian dalam melakukan penyidikan dalam kasus simulator SIM karena kedua lembaga tersebut sama-sama menyatakan berwenang. Penelitian ini merupakan penelitian yang bersifat normatif. Pendekatan penelitian yang digunakan meliputi pendekatan undang-undang, dan pendekatan kasus. Jenis data yang digunakan adalah data sekunder. Sumber data sekunder yang digunakan mencakup bahan hukum primer, bahan hukum sekunder dan bahan hukum tersier. Kesimpulan dari penelitian ini adalah dalam UU No . 30 Tahun 2002 tentang Komisi Pemberantasan Tindak Pidana Korupsi Pasal 50 menyatakan bahwa yang berwenang melakukan penyidikan adalah KPK, wewenang tersebut juga diperkuat oleh pernyataan Presiden Susilo Bambang Yudhoyono. Sebagai solusi kasus sengkarut antara KPK dengan Polri, dalam pidatonya 8 Oktober 2012 malam menyatakan antara lain bahwa penanganan hukum dugaan korupsi simulator SIM yang melibatkan Irjen Djoko Susilo agar ditangani KPK. Apalagi dengan adanya MoU antara KPK, Polri dan Kejagung maka yang lebih berwenang adalah KPK.
\end{abstract}

Kata kunci : Kewenangan, komisi pemberantasan korupsi, penyidikan. 


\section{Pendahuluan}

Salah satu pertimbangan dibentuknya lembaga Komisi Pemberantasan Tindak Pidana Korupsi sebagaimana tercantum dalam UU No. 30 Tahun 2002, bahwa lembaga pemerintah yang menangani perkara tindak pidana korupsi belum berfungsi secara efektif dan efisien dalam memberantas tindak pidana korupsi. ${ }^{1}$ Penegakan hukum terhadap tindak pidana korupsi yang dilakukan oleh institusi seperti Kejaksaan Republik Indonesia dan Kepolisian Republik Indonesia, dalam praktiknya sering menghadapi kendala dan dipandang tidak mandiri dan independen. ${ }^{2}$ Padahal, upaya pemberantasan korupsi harus mendapat dukungan dari berbagai kalangan.

Respon terhadap korupsi ada yang dilakukan dengan cara yang bersifat mengadili dan menjatuhkan pidana terhadap koruptor-koruptor dengan pidana yang setimpal agar dapat menjadi peringatan bagi koruptor untuk tidak berbuat lagi. Demikian juga apabila ada tindakan tegas maka hal ini akan menjadi contoh pula bagi masyarakat untuk tidak berbuat yang serupa. Pada saat negara kita dilanda gelombang korupsi yaitu sekitar tahun 1968an, Adnan Buyung Nasution pernah mengatakan bahwa: "TNI/AD hendaknya mempelopori pemberantasan korupsi sebagaimana dulu pernah dilakukan di tahun 1950an di jaman demokrasi parlementer."

Jadi apa yang dikemukakan oleh Adnan Buyung Nasution tersebut merupakan salah satu alternatif di dalam kepeloporan mengikis perbuatan korupsi. Terutama apabila para pelaku korupsi terdiri dari orang-orang atau para pejabat tinggi, yang dalam hal ini sering disebut melakukan "White Collar Crime" dan militer. ${ }^{3}$

Tetapi tidak jarang manakala kasus kejahatan sudah menyentuh para petinggi negara, penangannya akan berbelit-belit saling melindungi. Seperti misalnya kasus dugaan korupsi pengadaan alat simulator Surat Ijin Mengemudi (SIM) yang menyebabkan kerugian Negara mencapai hampir Rp. 100.000.000.000,00 ini telah menghebohkan masyarakat. ${ }^{4}$

\footnotetext{
${ }^{1}$ Lihat pertimbangan UU No. 30 Tahun 2002 tentang Komisi Pemberantasan Tindak Pidana Korupsi.

${ }^{2}$ Marwan Effendy, Kejaksaan RI Posisi dan Fungsinya dari Perspektif Hukum, Gramedia Pustaka Utama, Jakarta, 2005 hlm. 161.

${ }^{3}$ Artidjo Alkostar, Korupsi Politik Di Negara Modern, FH UII Press, Yogyakarta, 2008, hlm. 82.

${ }^{4}$ http://nasional.news.viva.co.id. Kpk terima penghitungan kerugian kasus simulator. Diakses tanggal 12 Oktober 2012.
} 
Kasus ini pertama kali mencuat saat Bambang Sukotjo, direktur PT Inovasi Teknologi Indonesia, membeberkan adanya dugaan suap proyek pengadaan simulator SIM di Korps Lalu Lintas (Korlantas) Mabes Polri. Bambang mengatakan bahwa ada suap dari perusahaan pemenang tender pengadaan simulator 2011, kepada pejabat Korlantas Polri berinisial DS sebesar Rp 2. 000.000.000,00. ${ }^{5}$

Ketegangan antara KPK dan Polri dimulai saat KPK melakukan penggeledahan di gedung Korps Lalu Lintas (Korlantas) Polri terkait kasus Simulator SIM. Sebenarnya baik KPK maupun Polri sudah sama-sama tahu bahwa masing-masing lembaga penegak hukum tersebut sedang menangani kasus yang sama di Korlantas Polri.

Kekisruhan terjadi antara KPK dan Polri terkait siapa yang berwenang melakukan penyelidikan pada kasus korupsi simulator SIM. Masing-masing pihak mengklaim lebih dulu mengeluarkan surat perintah penyelidikan (Sprinlid). Polri mengklaim penyelidikan kasus dugaan korupsi simulator SIM sesuai dengan Sprinlid /55/V/2012/Tipidkor Tanggal 21 Mei 2012, di mana Polri telah melakukan interogasi dan pengambilan keterangan dari 33 saksi yang dinilai tahu tentang pengadaan simulator SIM roda 2 dan roda 4. Apabila dilihat dari Sprinlid itu, maka otomatis Polri melakukan penyelidikan lebih dahulu, sebagaimana dikatakan Kabareskrim Mabes Polri Komjen Pol Sutarman. Sedangkan untuk penyidikan kasus ini, Sutarman menyebut tanggal 31 Juli 2012 sebagai tanggal permulaan. Padahal, KPK seperti disampaikan Wakil Ketua KPK Bambang Widjojanto, telah lebih dulu melakukan penyelidikan dan penyidikan kasus simulator SIM. KPK telah menyelidiki kasus ini sejak 20 Januari 2012 dan menaikkan ke tahap penyidikan tanggal 27 Juli $2012 .^{6}$

Polri bersikukuh ingin menangani kasus dugaan korupsi simulator SIM di Korlantas Polri yang juga sudah ditangani Komisi Pemberantasan Korupsi (KPK). Polri berdalih bisa menangani kasus itu karena adanya Memorandum of Understanding (MoU) antara KPK, Polri dan Kejagung. ${ }^{7}$ Padahal, beberapa pasal dalam MoU itu malah menguatkan KPK sebagai pihak yang seharusnya menangani kasus tersebut.

\footnotetext{
2012.

${ }^{5}$ http:/ / banjarmasin.tribunnews.com. Yusril beberkan solusi konflik kpk dan polri. Diakses tanggal 10 Oktober ${ }^{6}$ http:// news.detik.com. Diakses tanggal 10 Desember 2012.
} 


\section{Rumusan Masalah}

Berdasarkan uraian di atas rumusan masalahnya adalah, institusi manakah yang berwenang untuk melakukan penyidikan terhadap kasus simulator SIM? Adanya MoU antara KPK, Polri dan Kejagung siapa yang lebih berhak untuk melakukan penyelidikan terhadap kasus tersebut?

\section{Tujuan Penelitian}

Penelitian ini bertujuan ntuk mengetahui institusi manakah yang berwenang untuk melakukan penyidikan terhadap kasus simulator SIM.

\section{Metode Penelitian}

Penelitian ini merupakan penelitian yang bersifat normatif. Pendekatan penelitian yang digunakan meliputi pendekatan undang-undang, dan pendekatan kasus. Jenis data yang digunakan adalah data sekunder. Sumber data sekunder yang digunakan mencakup bahan hukum primer, bahan hukum sekunder dan bahan hukum tersier. Bahan-bahan hukum primer terdiri dari perundang-undangan, risalah dalam pembuatan perundang-undangan dan putusan-putusan hakim. ${ }^{8}$ Undang-undang yang diteliti adalah UU No. 30 Tahun 2002 tentang Komisi Pemberantasan Tindak Pidana Korupsi Pemilu Pasal 50 yang berkaitan dengan kewenangan KPK dan institusi penegak hukum lainnya dalam melakukan penyidikan. Teknik pengumpulan data yang digunakan berupa bahan pustaka melalui buku-buku literatur, peraturan perundang-undangan, serta pengumpulan data, melalui media elektronik yang berhubungan dengan masalah yang diteliti. Analisis yang digunakan adalah kualitatif. yaitu menganalisis data penelitian untuk selanjutnya dikaji secara mendalam dan diinterpretasikan oleh peneliti untuk mendapatkan kesimpulan yang diharapkan. ${ }^{9}$ Bahan hukum yang sudah disistematisasi kemudian dianalisis secara kualitatif.

\footnotetext{
${ }^{7}$ http:// news.detik.com. Diakses tanggal 6 Desember 2012.

${ }^{8}$ Peter Mahmud Marzuki, Penelitian Hukum, Edisi Pertama,Cetakan Ke-4, Predana Media Group, Jakarta, 2008, hlm. 141.

${ }^{9}$ Soeryono Soekanto, Pengantar Penelitian Hukum, UI Press, Jakarta, 2001, hlm. 24.
} 


\section{Hasil Penelitian dan Pembahasan}

\section{Tugas, Wewenang, dan Kewajiban KPK}

Fenomena korupsi telah mengambil tempat pada berbagai bentuk dan terdapat pada berbagai masyarakat atau bangsa. Dalam sejarahnya, korupsi oleh masyarakat dianggap sebagai sesuatu yang wajar atau lazim dalam kehidupan sehari-hari. Permasalahan korupsi menjadi gejala yang begitu sulit untuk dituntaskan di manapun. Berbagai upaya yang dilakukan untuk memberantas budaya korupsi, alih-alih hanya upaya untuk mengurangi sesedikit mungkin perilaku korupsi dapat terjadi. Namun, peluang bagi muncul dan mewabahnya korupsi pada tiap sistem dan struktur birokrasi di dunia senantiasa selalu ada. Sebagaimana dikatakan Mochtar Lubis: korupsi bukanlah sesuatu yang mutlak harus ada, dan tidak bisa dielakkan dalam masyarakat yang lagi berkembang. Kemungkinan sesuatu birokrasi dihinggapi penyakit korupsi selalu ada, baik di masyarakat yang sedang berkembang maupun masyarakat yang telah maju. ${ }^{10}$

Meningkatnya tindak pidana korupsi yang tidak terkendali akan membawa bencana tidak saja terhadap kehidupan perekonomian nasional tetapi juga terhadap kehidupan berbangsa dan bernegara pada umumnya. Tindak pidana korupsi yang meluas dan sistematis yang merupakan pelanggaran terhadap hak sosial dan hak ekonomi masyarakat. Oleh karena itu, tindak pidana korupsi tidak lagi dapat digolongkan sebagai kejahatan biasa melainkan telah menjadi suatu kejahatan luar biasa. Begitu pun dalam upaya pemberantasannya tidak lagi dapat dilakukan secara biasa, tetapi dituntut dengan cara-cara yang luar biasa. ${ }^{11}$

Penegakan hukum untuk memberantas tindak pidana korupsi yang dilakukan secara konvensional selama ini terbukti mengalami berbagai hambatan. Untuk itu diperlukan berbagai metode penegakan hukum secara luar biasa melalui pembentukan suatu badan khusus yang mempunyai kewenangan luas, independen, serta bebas dari kekuasaan mana pun dalam upaya pemberantasan tindak pidana korupsi, yang pelaksanannya dilakukan secara optimal, intensif, efektif, dan profesional. ${ }^{12}$

${ }^{10}$ Mochtar Lubis, Etika Pegawai Negeri, Yayasan Obor, Jakarta, 1997, hlm. 47. Dalam Mansyur Semma, Negara Dan Korupsi Pemikiran Mochtar Lubis Atas Negara, Manusia Indonesia, Dan Perilaku Politik, Yayasan Obor Indonesia, Jakarta, 2008, hlm. 218.

${ }^{11}$ Evi Hartanti, Tindak Pidana Korupsi, Edisi Kedua, Sinar Harapan Offset, Jakarta, 2008, hlm. 69.

${ }^{12}$ Ermansjah Djaya, Memberantas Korupsi Bersama KPK kajian Yuridis Normatif UU No. 31 Tabun 1999 jo. UU No. 20 Tahun 2001 Versi UU No. 30 Tahun 2002, Cet. Pertama, Sinar Grafika Offset, Jakarta, 2008, hlm. 183. 
Dalam rangka mewujudkan supremasi hukum, pemerintah Indonesia telah meletakkan landasan kebijakan yang kuat dalam usaha memerangi tindak pidana korupsi. Berbagai kebijakan tersebut tertuang dalam berbagai peraturan perundangundangan, antara lain dalam Tap MPR RI No. XI/MPR/1998 tentang Penyelenggaraan Negara yang Bersih dan Bebas Korupsi, Kolusi, dan Nepotisme, UU No. 28 Tahun 1999 tentang Penyelenggaraan Negara yang Bersih dan Bebas Korupsi, Kolusi, dan Nepotisme, serta UU No. 31 Tahun 1999 tentang Pemberantasan Tindak Pidana Korupsi sebagaimana diubah dengan UU No. 20 Tahun 2001 tentang Pemberantasan Tindak Pidana Korupsi. ${ }^{13}$

Berdasarkan ketentuan Pasal 43 UU No. 31 Tahun 1999 tentang Pemberantasan Tindak Pidana Korupsi sebagaimana diubah dengan UU No. 20 Tahun 2001, telah dibentuk badan khusus untuk menangani upaya pemberantasan korupsi. Badan khusus tersebut dalam UU No. 30 Tahun 2002 adalah Komisi Pemberantasan Tindak Pidana Korupsi yang selanjutnya disebut Komisi Pemberantasan Korupsi (KPK). Pembentukan KPK didasarkan pada kebutuhan untuk mendapatkan jaksa penuntut umum (JPU) yang independen dalam menangani kasus-kasus korupsi. ${ }^{14}$

Di samping itu, salah satu prinsip yang dapat dipergunakan untuk menjelaskan eksistensi KPK adalah adanya dalil yang berbunyi salus populi supreme lex, yang berarti "keselamatan rakyat (bangsa dan negara) adalah hukum yang tertinggi." Jika keselamatan rakyat, bangsa dan negara sudah terancam karena keadaan yang luar biasa maka tindakan apa pun yang sifatnya darurat atau khusus dapat dilakukan untuk menyelamatkannya. Dalam hal ini, kehadiran KPK dipandang sebagai langkah darurat untuk menyelesaikan korupsi yang sudah luar biasa. ${ }^{15}$

Komisi Pemberantasan Korupsi mempunyai tugas: ${ }^{16}$ a. koordinasi dengan instansi yang berwenang melakukan pemberantasan tindak pidana korupsi; $b$. supervisi terhadap instansi yang berwenang melakukan pemberantasan tindak pidana korupsi; c. melakukan penyelidikan, penyidikan, dan penuntutan terhadap tindak pidana korupsi; d. melakukan tindakan-tindakan pencegahan tindak pidana

\footnotetext{
${ }^{13}$ Jimly Asshiddiqie, Perkembangan dan konsolidasi Lembaga Negara Pasca Reformasi, Edisi Kedua Cetakan Pertama, Sinar Grafika, Jakarta, 2010, hlm. 198.

${ }^{14}$ M. Syamsudin, Faktor-Faktor Sosiolegal yang Menentukan dalam Penanganan Perkara Korupsi di Pengadilan, Jurnal Hukum, Vol. 17 No.3 Juli 2010, Yogyakarta, hlm. 416.

${ }^{15}$ Mahfud MD, Perdebatan Hukum Tata Negara Pasca Amandemen Konstitusi, Cetaka ke-2, PT RajaGrafindo Persada, Jakarta, 2011, hlm. 197.
} 
korupsi; dan e. melakukan monitor terhadap penyelenggaraan pemerintahan negara.

Dalam melaksanakan tugas koordinasi sebagaimana dimaksud dalam Pasal 6 huruf a, Komisi Pemberantasan Korupsi berwenang: ${ }^{17}$ a. mengkoordinasikan penyelidikan, penyidikan, dan penuntutan tindak pidana korupsi; b. menetapkan sistem pelaporan dalam kegiatan pemberantasan tindak pidana korupsi; c. meminta informasi tentang kegiatan pemberantasan tindak pidana korupsi kepada instansi yang terkait; d. melaksanakan dengar pendapat atau pertemuan dengan instansi yang berwenang melakukan pemberantasan tindak pidana korupsi; dan meminta laporan instansi terkait mengenai pencegahan tindak pidana korupsi.

Dalam melaksanakan tugas supervisi sebagaimana dimaksud dalam Pasal 6 huruf b, Komisi Pemberantasan Korupsi berwenang melakukan pengawasan, penelitian, atau penelaahan terhadap instansi yang menjalankan tugas dan wewenangnya yang berkaitan dengan pemberantasan tindak pidana korupsi, dan instansi yang dalam melaksanakan pelayanan publik. ${ }^{18}$ (2) Dalam melaksanakan wewenang sebagaimana dimaksud pada ayat (1), Komisi Pemberantasan Korupsi berwenang juga mengambil alih penyidikan atau penuntutan terhadap pelaku tindak pidana korupsi yang sedang dilakukan oleh kepolisian atau kejaksaan. (3) Dalam hal Komisi Pemberantasan Korupsi mengambil alih penyidikan atau penuntutan, kepolisian atau kejaksaan wajib menyerahkan tersangka dan seluruh berkas perkara beserta alat bukti dan dokumen lain yang diperlukan dalam waktu paling lama 14 (empat belas) hari kerja, terhitung sejak tanggal diterimanya permintaan Komisi Pemberantasan Korupsi. (4) Penyerahan sebagaimana dimaksud pada ayat (3) dilakukan dengan membuat dan menandatangani berita acara penyerahan sehingga segala tugas dan kewenangan kepolisian atau kejaksaan pada saat penyerahan tersebut beralih kepada Komisi Pemberantasan Korupsi.

Pengambilalihan penyidikan dan penuntutan sebagaimana dimaksud dalam Pasal 8, dilakukan oleh Komisi Pemberantasan Korupsi dengan alasan: ${ }^{19}$ a. laporan masyarakat mengenai tindak pidana korupsi tidak ditindaklanjuti; b. proses penanganan tindak pidana korupsi secara berlarut-larut atau tertunda-tunda tanpa alasan yang dapat dipertanggungjawabkan; c. penanganan tindak pidana korupsi

\footnotetext{
${ }^{17}$ Pasal 7 Ibid.

${ }^{18}$ Pasal 8 ayat (1) Ibid.

${ }^{19}$ Pasal 9 Ibid.
} 
ditujukan untuk melindungi pelaku tindak pidana korupsi yang sesungguhnya; $d$. penanganan tindak pidana korupsi mengandung unsur korupsi; e. hambatan penanganan tindak pidana korupsi karena campur tangan dari eksekutif, yudikatif, atau legislatif; atau f. keadaan lain yang menurut pertimbangan kepolisian atau kejaksaan, penanganan tindak pidana korupsi sulit dilaksanakan secara baik dan dapat dipertanggungjawabkan. Dalam hal terdapat alasan sebagaimana dimaksud dalam Pasal 9, Komisi Pemberantasan Korupsi memberitahukan kepada penyidik atau penuntut umum untuk mengambil alih tindak pidana korupsi yang sedang ditangani.

Dalam melaksanakan tugas sebagaimana dimaksud dalam Pasal 6 huruf c, Komisi Pemberantasan Korupsi berwenang melakukan penyelidikan, penyidikan, dan penuntutan tindak pidana korupsi yang : a. melibatkan aparat penegak hukum, penyelenggara negara, dan orang lain yang ada kaitannya dengan tindak pidana korupsi yang dilakukan oleh aparat penegak hukum atau penyelenggara negara; $b$. mendapat perhatian yang meresahkan masyarakat; dan/atau menyangkut kerugian negara paling sedikit Rp.1.000.000.000,00 (satu milyar rupiah). ${ }^{20}$

Dalam melaksanakan tugas penyelidikan, penyidikan, dan penuntutan sebagaimana dimaksud dalam Pasal 6 huruf c, Komisi Pemberantasan Korupsi berwenang: a. melakukan penyadapan dan merekam pembicaraan; b. memerintahkan kepada instansi yang terkait untuk melarang seseorang bepergian ke luar negeri; c. meminta keterangan kepada bank atau lembaga keuangan lainnya tentang keadaan keuangan tersangka atau terdakwa yang sedang diperiksa;d. memerintahkan kepada bank atau lembaga keuangan lainnya untuk memblokir rekening yang diduga hasil dari korupsi milik tersangka, terdakwa, atau pihak lain yang terkait; e. memerintahkan kepada pimpinan atau atasan tersangka untuk memberhentikan sementara tersangka dari jabatannya; f. meminta data kekayaan dan data perpajakan tersangka atau terdakwa kepada instansi yang terkait; g. menghentikan sementara suatu transaksi keuangan, transaksi perdagangan, dan perjanjian lainnya atau pencabutan sementara perizinan, lisensi serta konsesi yang dilakukan atau dimiliki oleh tersangka atau terdakwa yang diduga berdasarkan bukti awal yang cukup ada hubungannya dengan tindak pidana korupsi yang sedang diperiksa; h. meminta bantuan Interpol Indonesia atau instansi penegak hukum negara lain untuk melakukan pencarian, penangkapan, dan penyitaan barang

${ }^{20}$ Pasal 11 Ibid. 
bukti di luar negeri; i. meminta bantuan kepolisian atau instansi lain yang terkait untuk melakukan penangkapan, penahanan, penggeledahan, dan penyitaan dalam perkara tindak pidana korupsi yang sedang ditangani. ${ }^{21}$

Dalam melaksanakan tugas pencegahan sebagaimana dimaksud dalam Pasal 6 huruf d, Komisi Pemberantasan Korupsi berwenang melaksanakan langkah atau upaya pencegahan sebagai berikut : a. melakukan pendaftaran dan pemeriksaan terhadap laporan harta kekayaan penyelenggara negara; b. menerima laporan dan menetapkan status gratifikasi; c. menyelenggarakan program pendidikan antikorupsi pada setiap jenjang pendidikan; $d$. merancang dan mendorong terlaksananya program sosialisasi pemberantasan tindak pidana korupsi; e. melakukan kampanye antikorupsi kepada masyarakat umum; f. melakukan kerja sama bilateral atau multilateral dalam pemberantasan tindak pidana korupsi. ${ }^{22}$

Dalam melaksanakan tugas monitor sebagaimana dimaksud dalam Pasal 6 huruf e, Komisi Pemberantasan Korupsi berwenang: a. melakukan pengkajian terhadap sistem pengelolaan administrasi di semua lembaga negara dan pemerintah; b. memberi saran kepada pimpinan lembaga negara dan pemerintah untuk melakukan perubahan jika berdasarkan hasil pengkajian, sistem pengelolaan administrasi tersebut berpotensi korupsi; c. melaporkan kepada Presiden Republik Indonesia, Dewan Perwakilan Rakyat Republik Indonesia, dan Badan Pemeriksa Keuangan, jika saran Komisi Pemberantasan Korupsi mengenai usulan perubahan tersebut tidak diindahkan. ${ }^{23}$

Komisi Pemberantasan Korupsi berkewajiban : a. memberikan perlindungan terhadap saksi atau pelapor yang menyampaikan laporan ataupun memberikan keterangan mengenai terjadinya tindak pidana korupsi; 1 . memberikan informasi kepada masyarakat yang memerlukan atau memberikan bantuan untuk memperoleh data lain yang berkaitan dengan hasil penuntutan tindak pidana korupsi yang ditanganinya; 2. menyusun laporan tahunan dan menyampaikannya kepada Presiden Republik Indonesia, Dewan Perwakilan Rakyat Republik Indonesia, dan Badan Pemeriksa Keuangan; d. menegakkan sumpah jabatan; e. menjalankan tugas, tanggung jawab, dan wewenangnya berdasarkan asas-asas sebagaimana dimaksud dalam Pasal $5 .^{24}$

\footnotetext{
${ }^{21}$ Pasal 12 ayat (1) Ibid.

22 Pasal 13 Ibid.

${ }^{23}$ Pasal 14 Ibid.

${ }^{24}$ Pasal 14 Ibid.
} 
Spirit etos kerja di KPK dipengaruhi oleh adanya limitasi waktu dalam penanganan perkara. Hal ini sesuai dengan UU No. 30 Tahun 2002 tentang KPK, khususnya Pasal 58 Ayat (1) yang menegaskan “ Perkara tindak pidana korupsi diperiksa dan diputus oleh Pengadilan Tindak Pidana Korupsi dalam waktu 90 (Sembilan puluh) hari kerja terhitung sejak tanggal perkara dilimpahkan ke Pengadilan Tindak Pidana Korupsi".

Kondisi ini menuntut konsentrasi, stamina dan etos kerja yang tinggi dari aparat di KPK dan hakim di Pengadilan Tipikor. Tidak jarang dalam menyidangkan perkara TPK di Pengadilan Tipikor dapat sampai tengah malam. Hal yang sama juga dilakukan pada tahap proses penyidikan terkadang harus lembur, dan hal itu sudah menjadi komitmen bersama di lingkungan KPK. ${ }^{25}$

Sebagai kompensasi dari kerja ekstra yang dilakukan oleh KPK tersebut, maka dalam hal kesejahteraan karyawan, KPK memiliki mekanisme tersendiri yang berbeda dengan pegawai negeri lainnya. Para pegawai KPK mendapatkan gaji dan tunjangan yang mencukupi untuk keluarganya. Mereka juga mendapatkan asuransi jiwa, baik untuk kesehatan maupun untuk kematian. Dengan demikian, dalam bekerja mereka mendapatkan ketenangan, sehingga dapat fokus dan profesional. ${ }^{26}$

Sebagai perbandingan, keberhasilan Komisi serupa KPK di Negara-negara lain seperti Hongkong, Singapura, dan Malaysia didukung oleh banyak faktor yang melatarbelakangi, antara lain: ${ }^{27}$ a. negara-negara luas dan jumlah penduduknya relatif kecil. b. tingkat kesadaran hukum masyarakat relatif lebih tinggi dibandingkan Indonesia. c. tingkat kesejahteraan aparatur pemerintahan jauh lebih baik daripada aparatur pemerintah di Indonesia. d. pengawasan atau kontrol berjalan dengan baik di seluruh lini sehingga dapat dideteksi lebih dini penyimpangan yang dimungkinkan terjadi.

\section{Kedudukan, Tanggung Jawab, dan Susunan Organisasi}

Komisi Pemberantasan Korupsi berkedudukan di ibukota Negara Republik Indonesia dan wilayah kerjanya meliputi seluruh wilayah negara Republik Indonesia. Komisi Pemberantasan Korupsi dapat membentuk perwakilan di daerah provinsi. ${ }^{28}$ Komisi Pemberantasan Korupsi bertanggung jawab kepada publik atas pelaksanaan

\footnotetext{
${ }^{25}$ M. Syamsudin, Op. Cit., hlm. 421-422.

${ }^{26}$ Ibid..

${ }^{27}$ Marwan Effendy, Kejaksaan... Op.Cit., hlm. 182.

${ }^{28}$ Pasal 19 ayat (1) dan (2) Op. Cit.
} 
tugasnya dan menyampaikan laporannya secara terbuka dan berkala kepada Presiden Republik Indonesia, Dewan Perwakilan Rakyat Republik Indonesia, dan Badan Pemeriksa Keuangan. Pertanggungjawaban publik tersebut dilaksanakan dengan cara: a. wajib audit terhadap kinerja dan pertanggungjawaban keuangan sesuai dengan program kerjanya; b. menerbitkan laporan tahunan; dan c. membuka akses informasi. ${ }^{29}$

Komisi Pemberantasan Korupsi sebagaimana dimaksud dalam Pasal 3 terdiri atas: a. Pimpinan Komisi Pemberantasan Korupsi yang terdiri dari 5 (lima) Anggota Komisi Pemberantasan Korupsi; b. Tim Penasihat yang terdiri dari 4 (empat) Anggota; dan c. Pegawai Komisi Pemberantasan Korupsi sebagai pelaksana tugas. Pimpinan Komisi Pemberantasan Korupsi disusun sebagai berikut : a. Ketua Komisi Pemberantasan Korupsi merangkap Anggota; Dan b. Wakil Ketua Komisi Pemberantasan Korupsi terdiri atas 4 (empat) orang, masing-masing merangkap Anggota. Pimpinan Komisi Pemberantasan Korupsi adalah pejabat negara. Pimpinan Komisi Pemberantasan Korupsi adalah penyidik dan penuntut umum. Pimpinan Komisi Pemberantasan Korupsi bekerja secara kolektif. (6) Pimpinan Komisi Pemberantasan Korupsi adalah penanggung jawab tertinggi Komisi Pemberantasan Korupsi. ${ }^{30}$

Komisi Pemberantasan Korupsi berwenang mengangkat Tim Penasihat sebagaimana dimaksud dalam Pasal 21 ayat (1) huruf b yang diajukan oleh panitia seleksi pemilihan. 2. Panitia seleksi pemilihan sebagaimana dimaksud pada ayat (1) dibentuk oleh Komisi Pemberantasan Korupsi. (3) Panitia seleksi pemilihan mengumumkan penerimaan calon dan melakukan kegiatan mengumpulkan calon anggota berdasarkan keinginan dan masukan dari masyarakat. (4) Calon anggota Tim Penasihat sebagaimana dimaksud pada ayat (3) diumumkan terlebih dahulu kepada masyarakat untuk mendapat tanggapan sebelum ditunjuk dan diangkat oleh KomisiPemberantasan Korupsi berdasarkan calon yang diusulkan oleh panitia seleksi pemilihan. (5) Setelah mendapat tanggapan dari masyarakat, panitia seleksi pemilihan mengajukan 8 (delapan) calon anggota Tim Penasihat kepada Komisi Pemberantasan Korupsi untuk dipilih 4 (empat) orang anggota. (6) Kegiatan sebagaimana dimaksud pada ayat (1), ayat (2), ayat (3), ayat (4), dan ayat (5) dilakukan paling lambat 3 (tiga) bulan terhitung sejak tanggal panitia seleksi pemilihan dibentuk. Pasal 23 Tim Penasihat berfungsi memberikan nasihat dan pertimbangan

\footnotetext{
${ }^{29}$ Pasal 20 ayat (1) dan (2) Ibid.

${ }^{30}$ Pasal 21 Ibid.
} 
sesuai dengan kepakarannya kepada Komisi Pemberantasan Korupsi dalam pelaksanaan tugas dan wewenang Komisi Pemberantasan Korupsi. ${ }^{31}$

Pasal 24 (1) Anggota Tim Penasihat sebagaimana dimaksud dalam Pasal 22 adalah warga negara Indonesia yang karena kepakarannya diangkat oleh Komisi Pemberantasan Korupsi. (2) Pegawai Komisi Pemberantasan Korupsi sebagaimana dimaksud dalam Pasal 21 ayat (1) huruf c adalah warga Negara Indonesia yang karena keahliannya diangkat sebagai pegawai pada Komisi Pemberantasan Korupsi. (3) Ketentuan mengenai syarat dan tata cara pengangkatan pegawai Komisi Pemberantasan Korupsi diatur lebih lanjut dengan Keputusan Komisi Pemberantasan Korupsi. ${ }^{32}$

Pasal 25 (1) Komisi Pemberantasan Korupsi: 1. menetapkan kebijakan dan tata kerja organisasi mengenai pelaksanaan tugas dan wewenang Komisi Pemberantasan Korupsi; 2. mengangkat dan memberhentikan Kepala Bidang, Kepala Sekretariat, Kepala Sub bidang, dan pegawai yang bertugas pada Komisi Pemberantasan Korupsi; 3. menentukan kriteria penanganan tindak pidana korupsi. (2) Ketentuan mengenai prosedur tata kerja Komisi Pemberantasan Korupsi diatur lebih lanjut dengan Keputusan Komisi.

\section{Pemberantasan Korupsi}

Susunan Komisi Pemberantasan Korupsi terdiri atas Ketua Komisi Pemberantasan Korupsi dan 4 (empat) orang Wakil Ketua Komisi Pemberantasan Korupsi. Komisi Pemberantasan Korupsi membawahkan 4 (empat) bidang yang terdiri atas: a. Bidang Pencegahan; b. Bidang Penindakan; c. Bidang Informasi dan Data; dan d. Bidang Pengawasan Internal dan Pengaduan Masyarakat. Bidang Pencegahan membawahkan : a. Subbidang Pendaftaran dan Pemeriksaan Laporan Harta Kekayaan Penyelenggara Negara; b. Subbidang Gratifikasi; c. Subbidang Pendidikan dan Pelayanan Masyarakat; dan d. Subbidang Penelitian dan Pengembangan. Bidang Penindakan membawahkan : a. Subbidang Penyelidikan; b. Subbidang Penyidikan; dan c. Subbidang Penuntutan. Bidang Informasi dan Data membawahkan: a. Subbidang Pengolahan Informasi dan Data; 1. Sub bidang Pembinaan Jaringan Kerja Antarkomisi dan Instansi; 2. Sub bidang Monitor. Bidang Pengawasan Internal dan Pengaduan Masyarakat membawahkan: a. Sub bidang

\footnotetext{
${ }^{31}$ Pasal 22 Ibid.

${ }^{32}$ Pasal 24 Ibid.
} 
Pengawasan Internal; 1. Sub bidang Pengaduan Masyarakat. Sub bidang Penyelidikan, Sub bidang Penyidikan, dan Sub bidang Penuntutan, masing-masing membawahkan beberapa Satuan Tugas sesuai dengan kebutuhan sub bidangnya. 1. Ketentuan mengenai tugas Bidang-bidang dan masing-masing Subbidang sebagaimana dimaksud pada ayat (2), ayat (3), ayat (4), ayat (5), ayat (6), dan ayat (7) diatur lebih lanjut dengan Keputusan Komisi Pemberantasan Korupsi. ${ }^{33}$

Dalam melaksanakan tugas dan wewenangnya, Komisi Pemberantasan Korupsi dibantu oleh Sekretariat Jenderal yang dipimpin oleh seorang Sekretaris Jenderal. Sekretaris Jenderal diangkat dan diberhentikan oleh Presiden Republik Indonesia. Dalam menjalankan tugasnya Sekretaris Jenderal bertanggungjawab kepada Pimpinan Komisi Pemberantasan Korupsi. Ketentuan mengenai tugas dan fungsi Sekretariat Jenderal ditetapkan lebih lanjut dengan Keputusan Komisi Pemberantasan Korupsi. ${ }^{34}$

Komisi Pemberantasan Korupsi dapat melakukan kerja sama dengan pihak lain dalam rangka pengembangan dan pembinaan organisasi Komisi Pemberantasan Korupsi. ${ }^{35}$

\section{Penyidikan, Penyelidikan, dan Penuntutan}

Segala kewenangan yang berkaitan dengan penyelidikan, penyidikan, dan penuntutan yang diatur dalam Undang-Undang Nomor 8 Tahun 1981 tentang Hukum Acara Pidana berlaku juga bagi penyelidik, penyidik, dan penuntut umum pada Komisi Pemberantasan Korupsi. Ketentuan sebagaimana dimaksud dalam Pasal 7 ayat (2) Undang-Undang Nomor 8 Tahun 1981 tentang Hukum Acara Pidana tidak berlaku bagi penyidik tindak pidana korupsi sebagaimana ditentukan dalam Undang-Undang ini. ${ }^{36}$

Penyelidikan, penyidikan, dan penuntutan tindak pidana korupsi dilakukan berdasarkan hukum acara pidana yang berlaku dan berdasarkan Undang-Undang Nomor 31 Tahun 1999 tentang Pemberantasan Tindak Pidana Korupsi sebagaimana telah diubah dengan Undang-Undang Nomor 20 Tahun 2001 tentang Perubahan atas Undang-Undang Nomor 31 Tahun 1999 tentang Pemberantasan Tindak Pidana Korupsi, kecuali ditentukan lain dalam Undang-Undang ini. Penyelidikan,

\footnotetext{
${ }^{33}$ Pasal 26 Ibid.

${ }^{34}$ Pasal 27 Ibid.

${ }^{35}$ Pasal 28 Ibid.

${ }^{36}$ Pasal 38 Ibid.
} 
penyidikan, dan penuntutan dilaksanakan berdasarkan perintah dan bertindak untuk dan atas nama Komisi Pemberantasan Korupsi. Penyelidik, penyidik, dan penuntut umum yang menjadi pegawai pada Komisi Pemberantasan Korupsi, diberhentikan sementara dari instansi kepolisian dan kejaksaan selama menjadi pegawai pada Komisi Pemberantasan Korupsi. ${ }^{37}$

Komisi Pemberantasan Korupsi tidak berwenang mengeluarkan surat perintah penghentian penyidikan dan penuntutan dalam perkara tindak pidana korupsi. Komisi Pemberantasan Korupsi dapat melaksanakan kerja sama dalam penyelidikan, penyidikan, dan penuntutan tindak pidana korupsi dengan lembaga penegak hukum negara lain sesuai dengan peraturan perundang-undangan yang berlaku atau berdasarkan perjanjian internasional yang telah diakui oleh Pemerintah Republik Indonesia. Komisi Pemberantasan Korupsi berwenang mengkoordinasikan dan mengendalikan penyelidikan, penyidikan, dan penuntutan tindak pidana korupsi yang dilakukan bersama-sama oleh orang yang tunduk pada peradilan militer dan peradilan umum. $^{38}$

Penyelidik adalah Penyelidik pada Komisi Pemberantasan Korupsi yang diangkat dan diberhentikan oleh Komisi Pemberantasan Korupsi. Penyelidik melaksanakan fungsi penyelidikan tindak pidana korupsi. Jika penyelidik dalam melakukan penyelidikan menemukan bukti permulaan yang cukup adanya dugaan tindak pidana korupsi, dalam waktu paling lambat 7 (tujuh) hari kerja terhitung sejak tanggal ditemukan bukti permulaan yang cukup tersebut, penyelidik melaporkan kepada Komisi Pemberantasan Korupsi. Bukti permulaan yang cukup dianggap telah ada apabila telah ditemukan sekurang-kurangnya 2 (dua) alat bukti, termasuk dan tidak terbatas pada informasi atau data yang diucapkan, dikirim, diterima, atau disimpan baik secara biasa maupun elektronik atau optik. Dalam hal penyelidik melakukan tugasnya tidak menemukan bukti permulaan yang cukup, penyelidik melaporkan kepada Komisi Pemberantasan Korupsi dan Komisi Pemberantasan Korupsi menghentikan penyelidikan. ${ }^{39}$ Dalam hal Komisi Pemberantasan Korupsi berpendapat bahwa perkara tersebut diteruskan, Komisi Pemberantasan Korupsi melaksanakan penyidikan sendiri atau dapat melimpahkan perkara tersebut kepada penyidik kepolisian atau kejaksaan. Dalam hal penyidikan

\footnotetext{
${ }^{37}$ Pasal 39 Ibid.

${ }^{38}$ Pasal 40, 41, 42 Ibid.

${ }^{39}$ Pasal 43, 44 Ibid.
} 
dilimpahkan kepada kepolisian atau kejaksaan, kepolisian atau kejaksaan wajib melaksanakan koordinasi dan melaporkan perkembangan penyidikan kepada Komisi Pemberantasan Korupsi.

Penyidik adalah Penyidik pada Komisi Pemberantasan Korupsi yang diangkat dan diberhentikan oleh Komisi Pemberantasan Korupsi. Penyidik melaksanakan fungsi penyidikan tindak pidana korupsi. Dalam hal seseorang ditetapkan sebagai tersangka oleh Komisi Pemberantasan Korupsi, terhitung sejak tanggal penetapan tersebut prosedur khusus yang berlaku dalam rangka pemeriksaan tersangka yang diatur dalam peraturan perundangundangan lain, tidak berlaku berdasarkan Undang-Undang ini. Pemeriksaan tersangka dilakukan dengan tidak mengurangi hak-hak tersangka. ${ }^{40}$

Atas dasar dugaan yang kuat adanya bukti permulaan yang cukup, penyidik dapat melakukan penyitaan tanpa izin Ketua Pengadilan Negeri berkaitan dengan tugas penyidikannya. Ketentuan peraturan perundang-undangan yang berlaku yang mengatur mengenai tindakan penyitaan, tidak berlaku berdasarkan Undang-Undang ini. Penyidik wajib membuat berita acara penyitaan pada hari penyitaan yang sekurangkurangnya memuat: 1 . nama, jenis, dan jumlah barang atau benda berharga lain yang disita; 2. keterangan tempat, waktu, hari, tanggal, bulan, dan tahun dilakukan penyitaan; 3 . keterangan mengenai pemilik atau yang menguasai barang atau benda berharga lain tersebut; 4 . tanda tangan dan identitas penyidik yang melakukan penyitaan; dan 5. tanda tangan dan identitas dari pemilik atau orang yang menguasai barang tersebut.) Salinan berita acara penyitaan disampaikan kepada tersangka atau keluarganya. ${ }^{41}$

Untuk kepentingan penyidikan, tersangka tindak pidana korupsi wajib memberikan keterangan kepada penyidik tentang seluruh harta bendanya dan harta benda isteri atau suami, anak, dan harta benda setiap orang atau korporasi yang diketahui dan atau yang diduga mempunyai hubungan dengan tindak pidana korupsi yang dilakukan oleh tersangka. Setelah penyidikan dinyatakan cukup, penyidik membuat berita acara dan disampaikan kepada Pimpinan Komisi Pemberantasan Korupsi untuk segera ditindaklanjuti. ${ }^{42}$

\footnotetext{
${ }^{40}$ Pasal 45, 46 Ibid.

${ }^{41}$ Pasal 47 Ibid.

${ }^{42}$ Pasl 48, 49 Ibid.
} 


\section{Kewenangan Melakukan Penyidikan terhadap Kasus Simulator SIM}

Adanya permohonan fatwa kepada Mahkamah Agung terkait dualisme kewenangan penyidikan antara KPK dan Polri mengenai kasus korupsi Simulator SIM Korlantas Polri, dengan tersangka Irjen (Pol) Djoko Susilo mengindikasikan bahwa terdapat ketidakpastian hukum terhadap institusi mana sebenarnya yang lebih berwenang melakukan penyidikan. Padahal Pasal 50 UU No. 30 Tahun 2002 tentang Komisi Pemberantasan Tindak Pidana Korupsi sudah jelas menegaskan bahwa, (1) dalam hal suatu tindak pidana korupsi terjadi dan Komisi Pemberantasan Korupsi belum melakukan penyidikan, sedangkan perkara tersebut telah dilakukan penyidikan oleh kepolisian atau kejaksaan, instansi tersebut wajib memberitahukan kepada Komisi Pemberantasan Korupsi paling lambat 14 (empat belas) hari kerja terhitung sejak tanggal dimulainya penyidikan. (2) penyidikan yang dilakukan oleh kepolisian atau kejaksaan sebagaimana dimaksud pada ayat (1) wajib dilakukan koordinasi secara terus menerus dengan Komisi Pemberantasan Korupsi.(3) dalam hal Komisi Pemberantasan Korupsi sudah mulai melakukan penyidikan sebagaimana dimaksud pada ayat (1), kepolisian atau kejaksaan tidak berwenang lagi melakukan penyidikan. (4) dalam hal penyidikan dilakukan secara bersamaan oleh kepolisian dan/atau kejaksaan dan Komisi Pemberantasan Korupsi, penyidikan yang dilakukan oleh kepolisian atau kejaksaan tersebut segera dihentikan.

Penegakan hukum atau penerapan hukum dan proses peradilan atau proses di pengadilan merupakan unsur penting kepastian hukum. Tetapi dua hal di atas belum memadai untuk mencapai kepastian hukum, apalagi menjamin pemenuhan kebutuhan dan pemuasan kepentingan hukum pencari keadilan atau masyarakat luas pada umumnya. ${ }^{43}$

Bagaimanakah persoalan kepastian hukum (rechtszekerheid legal certainty)? Sebelum menjawab pertanyaan ini, perlu terlebih dahulu diuraikan mengenai lingkup kepastian hukum. Ada beberapa komponen kepastian hukum: ${ }^{44}$ (1) Kepastian hukum yang akan diterapkan; (2) kepastian proses hukum, baik dalam penegakan hukum maupun pelayanan hukum; (3) kepastian kewenangan yaitu kepastian lingkungan jabatan atau pejabat yang berwenang menetapkan atau mengambil suatu keputusan hukum; (4) kepastian waktu dalam setiap proses

${ }^{43}$ Bagir manan, Sistem Peradilan Berwibawa (Suatu Pencarian), Cet. Pertama, FH UII Press, Yogyakarta, 2005, hlm. 
hukum, dan (5) kepastian pelaksanaan, seperti kepastian eksekusi putusan hakim, atau keputusan administrasi negara.

Aneka ragam komponen kepastian tersebut membawa dampak pada sumber kepastian hukum. Ada beberapa sumber yang mendorong kepastian atau ketidakpastian hukum. (1) aturan-aturan hukum. Tidak jarang, suatu kepastian hukum tidak dapat ditentukan karena aturan hukum yang tidak dapat diketahui dengan pasti. Dalam hal peraturan perundang-undangan, ketidakpastian dapat timbul karena perbedaan atau pertentangan antara berbagai ketentuan yang ada (baik secara horizontal ataupun vertikal). Ketidakpastian peraturan perundangundangan dapat juga timbul karena rumusan yang tidak jelas, bahasa yang tidak baku dan tidak normatif. Tidak jarang pula, suatu kepastian hukum dipengaruhi oleh lambatnya menetapkan aturan pelaksanaan yang diperlukan. Akhir-akhir ini dijumpai "kegaduhan" mengenai wewenang penyidikan. Beberapa pengadilan menyatakan kejaksaan tidak berwenang melakukan penyidikan. Hal ini terjadi karena didapati berbagai undang-undang yang mengatur penyidikan dan penyidik (Kepolisian, Kejaksaan, KPK, Angkatan Laut dan lain-lain). (2) ketidakpastian hukum dapat juga bersumber pada pemerintah (administrasi negara). Kebijakan yang tidak konsisten dan acapkali berubah, keputusan yang di tunda-tunda (lambat), banyaknya aturan kebijakan (beliedsregels), pembagian wewenang yang tidak jelas dan berbagai bentuk overlapping hubungan antar berbagai lingkungan jabatan (seperti hubungan Pusat dan Daerah), merupakan sumber-sumber ketidakpastian hukum. (3) putusan hakim. Putusan hakim yang tertunda-tunda, tidak ada konsistensi putusan mengenai objek yang serupa juga merupakan anggapan bahwa putusan hakim merupakan sumber utama, bahkan satu-satunya sumber ketidakpastian hukum. ${ }^{45}$

Terkait dengan kasus simulator SIM yang menjadi sengketa kewenangan penyidikan antara KPK dan Polri karena kedua lembaga ini sama-sama ingin menyidik kasus tersebut. Menanggapi persoalan itu, Yusril Ihza Mahendra menyatakan bahwa, Polri mempunyai kewenangan yang lebih kuat dibandingkan KPK karena kewenangan Polri diatur dalam Pasal 30 UUD, sedangkan kewenangan KPK hanya diatur dalam Undang-Undang. ${ }^{46}$

\footnotetext{
${ }^{44}$ Bagir manan, Kekuasaan Kehakiman Indonesia Dalam UU No. 4 Tahun 2004, Cetakan Pertama, FH UII Press, Yogyakarta, 2004, hlm. 20.

${ }^{45}$ Ibid.

${ }^{46}$ http:/ / www.metrotvnews.com.Yusril Kewenangan Polri Lebih Kuat dari KPK. Diakses tanggal 2 Oktober 2012
} 
Sedangkan pakar hukum pidana Universitas Indonesia, Gandjar Laksmana Bonaparta menegaskan langkah KPK sudah tepat dalam menangani kasus simulator SIM. Bunyi Pasal 50 ayat (3) Undang-Undang KPK sudah sangat jelas, tidak ada yang multitafsir. Menurut Gandjar, berdasarkan aturan, KPK yang lebih berwenang mengusut kasus korupsi tersebut meskipun kedua lembaga sama-sama berdasarkan pada ketentuan hukum. Aturan menyelesaikan perselisihan penanganan kasus korupsi hanya ada dalam Undang-Undang KPK, tidak ditemukan dalam KUHP maupun Undang-Undang Kepolisian. Bahwa ada asas hukum lex specialis derogat legi generali artinya, hukum yang bersifat khusus mengesampingkan hukum yang bersifat umum. Sehingga, penerapan KUHP harusnya dikesampingkan dengan adanya UU KPK dalam pengusutan kasus korupsi simulator SIM tersebut. Di samping itu ada juga asas, ketentuan hukum yang lebih baru mengesampingkan ketentuan hukum sebelumnya." ${ }^{47}$

Menurut UU No. 30 Tahun 2002 tentang Komisi Pemberantasan Tindak Pidana Korupsi, KPK dapat mengambilalih terhadap menyidikan suatu kasus apabila ada sebab-sebab tertentu sebagaimana ditentukan oleh UU. Misalnya, penyidikan berlarut-larut, mengandung korupsi, atau Polri ingin melindungi mereka yang terlibat dalam korupsi.

Bagaimana sebetulnya bunyi kesepakatan antar kedua instansi hukum itu soal penanganan tindak pidana korupsi, jika masing-masing merasa paling berwenang melakukan penyelidikan dan penyidikan? Kesepakatan itu tertuang dalam Kesepakatan Bersama Antara Kejaksaan Republik Indonesia, Kepolisian Negara Republik Indonesia, Komisi Pemberantasan Korupsi Republik Indonesia. Nomor: KEP-049/A/J.A/03/2012, nomor: B/23/III/2012, dan nomor: SP3-39/01/03/2012 Tentang Optimalisasi Pemberantasan Tindak Pidana Korupsi. Berikut kesepakatan dimaksud yang ditandatangani pada tanggal 29 Maret 2012 di Kejagung, yaitu bagian kedua tentang Penanganan Perkara Tindak Pidana Korupsi, Pasal 8 MoU disebutkan: 1. dalam hal para pihak melakukan penyelidikan pada sasaran yang sama, untuk menghindari duplikasi penyelidikan, maka penentuan instansi yang mempunyai kewajiban untuk menindaklanjuti penyelidikan adalah instansi yang lebih dahulu mengeluarkan surat perintah penyelidikan atau atas kesepakatan para pihak. 2. penyidikan yang dilakukan pihak kejaksaan dan pihak Polri diberitahukan kepada

${ }^{47}$ http://www.tempo.co. Polisi Punya Yusril KPK Dibela Gandjar. Diakses tanggal 8 Oktober 2012. 
pihak KPK, dan perkembangannya diberitahukan kepada pihak KPK paling lama tiga bulan sekali; 3. pihak KPK menerima rekapitulasi penyampaian bulanan atas kegiatan penyidikan yang dilaksanakan oleh kejaksaan dan pihak Polri; 4. penyelidikan dan penyidikan tindak pidana korupsi oleh salah satu pihak dapat dialihkan ke pihak lain sesuai ketentuan peraturan perundang-undangan, dengan terlebih dahulu dilakukan gelar perkara yang dihadiri oleh para pihak yang pelaksanaannya dituangkan dalam berita acara. ${ }^{48}$

Jika mengacu pada pasal 8 poin 1 dan poin 4, maka KPK adalah lembaga yang lebih berhak menangani kasus simulator SIM. Poin 1 menguatkan KPK pada sisi terlebih dulu memulai penyelidikan kasus. Sedangkan poin 4 menguatkan KPK dengan adanya UU KPK No. 30 Tahun 2002 Pasal 50 yang menyebut KPK berhak mengambil alih kasus korupsi yang ditangani lembaga lain. ${ }^{49}$

Sebagai solusi kasus sengkarut antara KPK dengan Polri, akhirnya Presiden Susilo Bambang Yudhoyono (SBY) dalam pidatonya tanggal 8 Oktober 2012 malam menyatakan antara lain bahwa, ${ }^{50}$ Penanganan hukum dugaan korupsi simulator SIM yang melibatkan Irjen Djoko Susilo agar ditangani KPK dan tidak pecah, Polri menangani kasus-kasus lain yang tidak terkait langsung; Perselisihan yang menyangkut waktu penugasan penyidik Polri yang bertugas di KPK perlu diatur kembali dan akan saya tuangkan dalam peraturan pemerintah, saya berharap nantinya teknis pelaksanaan juga diatur dalam MoU antara KPK dan Polri; dan berharap agar KPK dan Polri dapat memperbarui MoU-nya dan kemudian dipatuhi dan dijalankan serta dilakukan sinergi sehingga peristiwa seperti ini tidak terus berulang di masa depan.

Banyak pihak yang menilai langkah tegas yang diambil oleh Presiden SBY ini adalah tepat untuk mengakhiri konflik berkepanjangan antara KPK dengan Polri. Sekarang yang penting adalah bagaimana ketiga lembaga penegak hukum yang ada (kejaksaan, kepolisian dan KPK) bersinergi untuk menyelesaikan kasus-kasus korupsi yang perlu penanganan serius. Masing-masing lembaga tidak boleh merasa paling dominan, paling kuat dari lembaga penegak hukum yang lain. Demikian juga KPK tidak boleh over manakala akan mengerjakan sesuatu, kerjakan dulu biar nanti media yang mengekspos hasil dari kinerja KPK. Lebih baik sekarang kembali

\footnotetext{
${ }^{48}$ http://news.detik.com. Op. Cit.

${ }^{49}$ Ibid.

${ }^{50}$ http:/ / www.metrotvnews.com. Ini Pidato Lengkap SBY Soal Solusi Sengkarut KPK Polri. Di akses tanggal
} 
kepada "khitah" artinya, awal mula kelahiran KPK karena lembaga pemerintah yang menangani perkara tindak pidana korupsi belum berfungsi secara efektif dan efisien dalam memberantas tindak pidana korupsi. ${ }^{51}$ Dengan demikian, KPK harus kuat, kejaksaan harus kuat, kepolisian juga harus kuat. Suatu saat nanti, jika lembaga kejaksaan dan kepolisian sudah dapat bekerja secara optimal dan prestasi kerjanya melebihi apa yang telah dilakukan oleh KPK, bisa jadi keberadaan KPK tidak dibutuhkan lagi. Untuk itu, adanya usulan agar keberadaan KPK diakomodir dalam UUD 1945 supaya mempunyai payung hukum yang kuat dan tidak selalu "direcoki" belum perlu karena UU KPK yang ada saat ini masih kuat.

\section{Penutup}

Pasal 50 ayat (4) menyatakan bahwa dalam hal penyidikan dilakukan secara bersamaan oleh kepolisian dan/atau kejaksaan dan Komisi Pemberantasan Korupsi, penyidikan yang dilakukan oleh kepolisian atau kejaksaan tersebut segera dihentikan. Dalam hal kasus simulator SIM, kepolisian mengklaim bahwa pihaknya adalah yang pertama kali melakukan menyidikan sementara, KPK mengklaim bahwa pihaknya yang lebih berwenang, KPK dan kepolisian sama-sama menyatakan berwenang melakukan penyidikan terhadap kasus tersebut. Tarik ulur penyidikan mengenai kasus simulator SIM menimbulkan sengketa yang berlarut-larut antara KPK dan Kepoisian. Akhirnya, sebagai solusi kasus sengkarut Presiden SBY mengeluarkan pernyataan bahwa, Penanganan hukum dugaan korupsi simulator SIM yang melibatkan Irjen Djoko Susilo agar ditangani KPK. Adanya MoU antara KPK, Polri dan Kejagung maka yang lebih berhak untuk melakukan penyelidikan terhadap kasus simulator SIM adalah KPK.

\section{Daftar Pustaka}

Alkostar, Artidjo, Korupsi Politik Di Negara Modern, FH UII Press, Yogyakarta, 2008.

Asshiddiqie, Jimly, Perkembangan E konsolidasi Lembaga Negara Pasca Reformasi, Edisi Kedua Cetakan Pertama, Sinar Grafika, Jakarta, 2010.

Djaya, Ermansjah, Memberantas Korupsi Bersama KPK kajian Yuridis Normatif UU No. 31 Tahun 1999 jo. UU No. 20 Tahun 2001 Versi UU No. 30 Tahun 2002, Cet. Pertama, Sinar Grafika Offset, Jakarta, 2008.

\footnotetext{
${ }^{51}$ Lihat huruf b pertimbangan UU No. 30 Tahun 2002 tentang Komisi Pemberantasan Tindak Pidana Korupsi.
} 
Effendy, Marwan, Kejaksaan RI Posisi dan Fungsinya dari Perspektif Hukum, Gramedia Pustaka Utama, Jakarta, 2005.

Hartanti, Evi, Tindak Pidana Korupsi, edisi Kedua, Sinar Harapan Offset, Jakarta, 2008.

Mahfud MD., M., Perdebatan Hukum Tata Negara Pasca Amandemen Konstitusi, Cetakan ke-2, PT RajaGrafindo Persada, Jakarta, 2011.

Mahmud Marzuki, Peter, Penelitian Hukum, Edisi Pertama, Cetakan Ke-4, Predana Media Group, Jakarta, 2008.

Manan, Bagir, Sistem Peradilan Berwibawa (Suatu Pencarian), Cet. Pertama, FH UII Press, Yogyakarta, 2005.

, Kekuasaan Kehakiman Indonesia Dalam UU No. 4 Tahun 2004, Cetakan Pertama, FH UII Press, Yogyakarta, 2004.

Semma, Mansyur, Negara Dan Korupsi Pemikiran Mochtar Lubis Atas Negara, Manusia Indonesia, dan Perilaku Politik, Yayasan Obor Indonesia, Jakarta, 2008.

Soekanto, Soeryono, Pengantar Penelitian Hukum, UI Press, Jakarta, 2001

Syamsudin, M., Faktor-Faktor Sosiolegal yang Menentukan dalam Penanganan Perkara Korupsi di Pengadilan, Jurnal Hukum, Vol. 17 No. 3 Juli 2010, Yogyakarta.

UU No. 30 Tahun 2002 tentang Komisi Pemberantasan Tindak Pidana Korupsi

http:/ / nasional.news.viva.co.id. Kpk terima penghitungan kerugian kasus simulator. Diakses tanggal 12 Oktober 2012.

http:/ /banjarmasin.tribunnews.com. Yusril beberkan solusi konflik kpk dan polri. Diakses tanggal 10 Oktober 2012.

http://www.seruu.com. Investigasi kpk mk ky artikel yusril kpk bias ambil alih kasus simulator sim dengan tiga syarat.

http:/ / www.metrotvnews.com.Yusril Kewenangan Polri Lebih Kuat dari KPK. Diakses tanggal 2 Oktober 2012

http:/ / www.tempo.co. Polisi Punya Yusril KPK Dibela Gandjar. Diakses tanggal 8 Oktober 2012.

http: / / www.metrotvnews.com. Ini Pidato Lengkap SBY Soal Solusi Sengkarut KPK Polri. Di akses tanggal 12 Oktober 2012.

http:/ / news.detik.com. 